Ahmed, A.L.M. (2018). The social background of Brexit. Copernican Journal of Finance \& Accounting, 7(4), 9-29. http://dx.doi.org/10.12775/CJFA.2018.017

\author{
Ahmed L.M. Ahmed* \\ Cracow University of Economics \\ Université de Grenoble Alpes in France
}

\title{
THE SOCIAL BACKGROUND OF BREXIT
}

Keywords: Brexit, British identity, national identity, European Union.

\section{J E L Classification: F50, N44.}

\begin{abstract}
The Brexit referendum will remain as a milestone in contemporary European history. The British exit from the EU is not going only to shape future relations between the EU and the UK, but it will shape the relation between Brussels and other member states as well. This study aims to investigate the main claims for the leave campaigns which affected the general opinion to vote for the exit. The two main points investigated in this paper are: first, the historical background regarding the UK and the EU, the reasons for the first refusal to the European integration projects during the 1950, and the changes in the British situation which pushed the UK to seek the membership for a decade before being able to join the EEC in the 1970s; and second, national identity, which affected Britain's late entry to the EU, and shaped relations between London and Brussels during the British membership. The paper concludes that, unfortunately, British citizens in general were not aware of the full facts regarding the above two points.
\end{abstract}

\section{IIITRODUCTION}

On June 23 $3^{\text {rd }}, 2016$, the British held their famous referendum to determine whether to stay or opt out from the European Union. Regardless of one's agree-

Date of submission: April 11, 2019; date of acceptance: April 29, 2019.

* Contact information: alm.ahmed@icloud.com, 5 Rue du Dr Mazet, 301 Residence Cardinal Stendhal, Grenoble 28000, France, phone: +33651664618; ORCID ID: https:// orcid.org/0000-0002-5961-6251. 
ment or disagreement with the results of that referendum, it will remain a milestone in the history of Europe for many years. The results of that referendum were like a bomb, which exploded with full force and violence and lead to a messy situation in the financial markets and the political scene, including the resignation of Prime Minister David Cameron, the fall of the pound to its lowest level in more than 30 years against the dollar, and the loss of the AAA credit rating for the UK for the first time since 1978, to AA with negative outlook by Moody's, Standard and Poor's, and Fitch. It has also threatened the unity of the kingdom: Scotland wants to organize a new referendum to stay or leave, and Northern Ireland may want to unify with Ireland. In addition, populist parties in many countries are calling for a similar referendum over EU membership, especially in countries always considered pillars of the EU like Germany and France.

The UK always had a special position in the EU, with many opt outs from the EU agreements. Even before the beginnings of the EU, UK was an outlier, refusing to join the European Steel and Coal Community in 1952. After two refusals from the French President Charles De Gaulle, UK joined the EEC in 1973 following that by a referendum of the membership with results of $67.23 \%$ for Yes, and $32.77 \%$ for No. In spite of its joining, the UK always represented the Apple of Eris, often in discord with EU policies. Brussels indulgently accepted and agreed to many exceptions for the UK, which encouraged the British to go ahead and ask for still more exceptions. Did that treatment create a feeling of superiority, which led to the exit? They opted out of the Schengen area agreement, although it now includes non-EU states such as Norway and Iceland (1996) and Switzerland (2009), and also the Economic Monetary Union (EMU) which created the Eurozone, while non-EU States such as Kosovo and Montenegro have unilaterally adopted the Euro as official currency.

After the shock of the referendum's results, the main question all over Europe was "why did they decide to leave?" This paper examines the causes and motives behind the leave decision, contributing to several important areas of current controversy, including the UK's relations within the EU. This paper makes use of literature reviews, official documents, data and statistics compiled by official bodies such as the European Union institutions and the British government, to determine the validity of the British or European position on the issues discussed and of the final decision made at that time.

The purpose for this paper is not only to investigate and understand the causes and motives behind the decision of that divorce, and to examine their 
veracity but also to understand these motives in order to avoid repeating this problem with other member states of the EU, especially with clouds appearing on the horizon of relations between Brussels and some member states such as Hungary. This study will analyse and contribute to several important areas of current controversy, including the UK's relations within the EU.

The following section is for the methodology and data sources used for this paper. Section 3 and 4 are an historical overview regarding the UK and the EU, the reasons for the first refusal to the European integration projects during the 1950, and the changes in the British situation which pushed the UK to seek the membership for a decade before being able to join the EEC in the 1970s. Section 5 argues that the primary reason behind the 1950's refusal was the British pride of their national and cultural identity and discusses the populist movements rising in the UK and the issue of sovereignty. Section 6 is for the cost of the Brexit and the $7^{\text {th }}$ and last section of the paper is dedicated to the conclusion.

\section{THE RESEARCH METHODOLOGY AND THE COURSE OF THE RESEARCH PROCESS}

This paper makes use of literature reviews, official documents, data and statistics compiled by official bodies such as the European Union institutions and the British government, to determine the validity of the British or European position on the issues discussed and of the final decision made at that time. I also use scientific articles and media sources discussing Brexit and relations between the UK and Europe.

\section{HISTORICAL BACKGROUND}

After each of the two world wars, there were attempts at greater European integration. The initiative always came from France, in 1929 with Briand's plan - formed by the former French Prime Minister Aristide Briand - to create a federal union of Europe "without affecting the sovereignty of any nation" (Saint-John Perse Foundation, 1929). After the Second World War, French Foreign Minister, Robert Schuman, expressed saying "Europe will not be made all at once... The coming together of the nations of Europe requires the elimination of the age-old opposition of France and Germany." As a result, following the Schuman plan, the Treaty of Paris was signed in 1951 founding the European Coal and Steal Community (ECSC). 
The UK chose to be absent from the European scene at that time, refusing to participate in the European convergence projects. Daddow (2004) states that the refusal for the European integration projects during the 1950s can be described according to three historical schools. "The missed opportunity" school argues that Britain has moved away from Europe in the post-war period because of its doubts in the Schuman plan and the common market. "The revisionist" school believes that UK didn't miss the "European bus" because it wanted to miss it, so much as it didn't even recognize the existence of the bus to catch it. The third school can be called "post-revisionism".

In September 1946, during his speech in the University of Zurich, Winston Churchill stated that what would make Europe free and happy was to re-create the European family, stressing that "we must build a kind of United States of Europe" (The Churchill Society, 1946). However, the UK considered itself a great power side by side with the United States and the Soviet Union, in particular after its participation in the Potsdam Conference in 1945 to discuss the rearrangement of Europe in the post-war phase (the UK was the only European representative in the Tehran, Yalta, and Potsdam conferences). Thus Churchill preferred a limited role for the UK, and he was pointing in his speech to the cooperation between France and Germany as a way of rapprochement between them thinking that the future of the UK would consist of stronger links with the US and the Commonwealth (Jones, 2001).

In October 1949, Hector McNeil, the Minister of State under Foreign Secretary Ernest Bevin, was convinced that the natural partners for the UK were the US and the Commonwealth, not Europe, considering that "anti-European feeling is a commonplace of British thought. Everyone had relatives in the USA and Canada. Most have no one in Europe, except the dead of the two wars" (Becker \& Knipping, 1986). Anti-European feeling was re-described by another Eurosceptic politician, Harold Macmillan, the former Prime Minister of the UK, when he was a Foreign Secretary in 1955. Considering the plans by the ECSC for the common market to be in the interest of Germany, he stated: "We did not mind other European Powers federating if they wished, but in fact if they did so and really became strong it might be very embarrassing for us. Europe would be handed over to the Germans, a state of affairs which we had fought two wars to prevent" (Ellison, 2000). When Macmillan became the Prime Minister, in a meeting organized by the UK Council of the European Movement in July 9, 1957, he described the Commonwealth as a living force which was understood and cher- 
ished by the British, as they knew how it was formed, and the historical association and common interest that bind the UK and the Commonwealth together.

These statements by British officials suggest that the main reasons for not feeling European for the British, were:

- greater concern for the US and the Commonwealth not only for language reasons, but also as a reflection of the memories of the British Empire, especially during the $19^{\text {th }}$ and early $20^{\text {th }}$ centuries, when the British Empire reached the largest territorial size in its history.

- the belief that being European is not in the interest of the UK, given that other countries are leading the EU (Germany and France specifically). Such a situation cannot be accepted psychologically by the British who are used to being leaders, not led.

- a sense of greater stability than most of Europe, considering that the UK alone had not faced any political occupation for the last 950 years, and had kept the same borders longer than any other European country; conflicts between the three nations of Great Britain (England, Wales and Scotland) had been settled long ago, and the three nations merged under one crown.

Thus, it is understandable why during the 1950s, Prime Ministers during that era, Clement Attlee, Winston Churchill, and Harold Macmillan, were against participating in the European integration projects, refusing for example to join the Treaty of Rome (1957) which created the European Economic Community (EEC), thinking that it did not add anything for them. The UK believed that they did not need Europe as much as Europe needed them; they had a better situation than any other European county after WWII, good trade links with the commonwealth and the rest of the world, and a different and special democratic and constitutional system. Moreover, Britain had the highest GDP per capita in Europe (Jones, 2001). These feelings were described by Jean Monnet, who wanted the UK in the EEC from the beginning: "It must have been because it was the price of victory, the illusion that you could maintain what you had, without change" (May, 1999).

However, Porter (1983) argues that the British refusal to join the EEC in the beginning was a confession of its failure to defend and determine its own interests. Furthermore, as a reply on the EEC, the UK tried in 1956 to establish a Wide European Free Trade Area but the project failed after two years of negotiations. However, it repeated the attempt again in 1960 and established the European Free Trade Association (EFTA) with Austria, Denmark, Portugal, 
Sweden, and Switzerland. The EFTA was considered not as strong as the EEC because the UK was the only powerful country in it (Steinnes, 1998).

\section{THE LOST SHEEP BACK TO THE FOLD}

By the early years of the 1970s the Commonwealth became a non-realistic economic target option for the UK, due to several successive events during the 1960s such as international monetary relations changes, and the Kennedy Round which negatively affected trade preferences, as well as the growing role of the US and the weakness which affected the relations with the Commonwealth (May, 2001). Thus, it is understandable that the weakness which affected the relations with the Commonwealth led to a weakening of the British loyalty to it, and of the refusals for integration with its European neighbours.

Urwin (1991) argues that the main reason for trying to join the EEC was to enhance the British economy, in particular with development of the EEC. The first attempt to join the EEC was in 1961, when the British government, regardless of motivations, concluded that membership in the EEC had become essential, and that Europe was more attractive than before. The request was vetoed by the French President, Charles de Gaulle in 1963, saying that "England is not much anymore" (The Guardian Newspaper, 2012), and that "The UK has the Commonwealth and France has the community" (Milward, 2002) putting into consideration that the French gross national product was growing by $5.8 \%$ per year during the 1960s. The second attempt was in 1967, and again it was vetoed by the French President, considering that the UK was more interested in links and ties with the US and the Commonwealth because "it is an island", and accusing it of responding to the first refusal with a "hostile attitude as if she saw in it an economic and political threat" (De Gaulle, 1967). Shawcross (2002) argues that the two applications were "humiliatingly" rejected and that the UK was accepted only when de Gaulle was gone. However, the second refusal showed the discord on enlargement between the member states as five of them plus the Commission agreed on the British joining; however, they couldn't persuade France, and the attempt was ended by imposing the French refusal (Martin, 2013). The UK was only able to join the EEC in 1973 after signing the treaty in January 1972, after the departure of de Gaulle from power.

A referendum was held in June 1975, as a part of the pledges by the Labour party during the 1974 electoral campaign to give the British people the right to choose between staying or leaving the common market (the European Com- 
munity) (The Labour Party Manifesto, 1974). The question of the referendum was "Do you think the United Kingdom should stay in the European Community (the Common Market)?" The result was that $67.23 \%$ voted for yes, $32.77 \%$ voted for no, while $0.21 \%$ were invalid votes. In 2016, another referendum was held. The question for the new one was almost the same: "Should the United Kingdom remain a member of the European Union or leave the European Union?" However, the votes were not the same as they were 41 years earlier, $51.89 \%$ voted for leaving while $48.11 \%$ voted for remain, and $0.08 \%$ were invalid votes.

\section{WHAT THE BRITISH FEEL TOWARDS EUROPE AND HOW THEY SEE THE EU}

After a decade of attempts to join the EEC, the UK still had few ties with the other member states in the Union. In 2011, during an interview with Le Monde newspaper, former French President Nicolas Sarkozy indicated that the EU wanted more solidarity between its member states, adding that the UK is "attached solely to the logic of the single market" (BBC, 2011). Thus, it is understood that this selective policy of the UK towards the EU created a general impression that the UK is "step in, step out", and that it seeks only its own interests. Moreover, another impression throughout Europe is that, within the European community the British are the least likely to identify personally as European, preferring their national identity to the European one. Wall (2008) considered that the key problem for the estrangement between the British point of view and the European point of view concerning European integration is the late entry to the EEC. However, he argues that the main reason for the differences between the two points of view is tied to historical and cultural considerations

\section{British nationalism and the sense of European identity}

One of the questions asked by the Eurobarometer of people throughout the EU is whether they feel themselves to be their nationality only, European only, their nationality and European, or European and their nationality. Answers to this question can be considered a good indicator of a people's feelings and their priorities, collectively, and whether they consider themselves first and foremost in relation to their nationality, with or without being European, or as Europeans preferring this to their nationality. When this question had been asked in 1996, the British answer was closely similar to those of several other EU nations and not as negative as many. Figure 1 shows the difference between situation in 
1996 and $2016^{1}$. Aside from the UK, where the nationalistic feeling increased by $5 \%$, only two countries have witnessed an increase: in Greece, the percentage has risen slightly, from 53 to $55 \%$, but in Italy the increase is $17 \%$, to $43 \%$ in total, but still far below the percentage in the UK even 20 years earlier.

Figure 1. Do you see yourself as your nationality only?

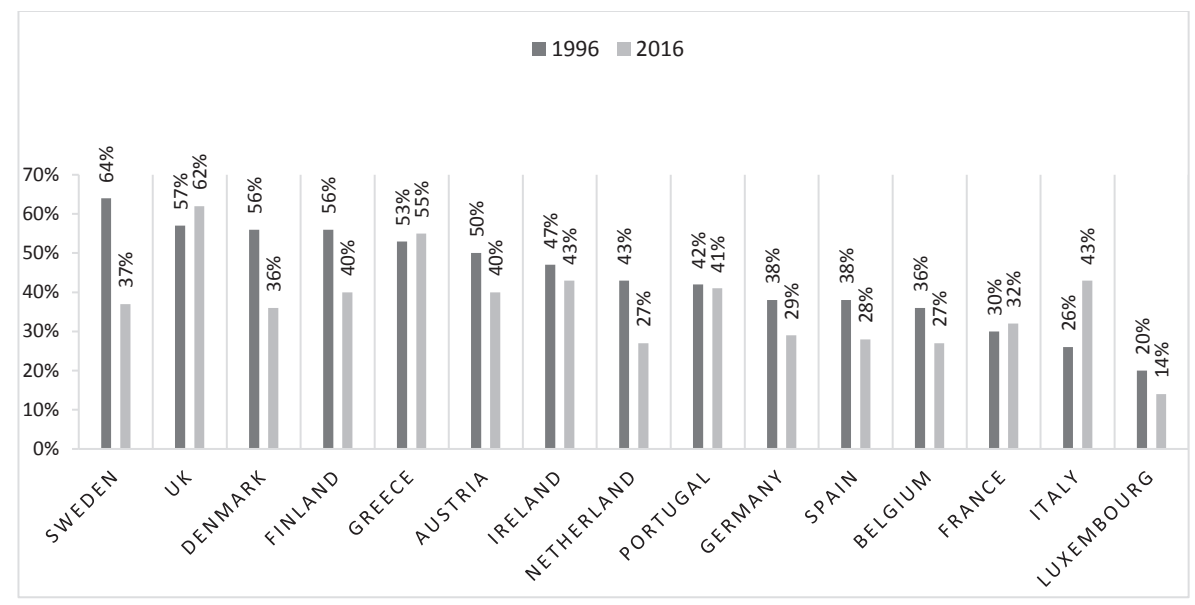

So u r c e : based on data from: (www1).

\section{How much the British cared about the EU?}

Not only did the British citizens not care about the EU, they also neglected to learn more about the EU or the relations between their country and the EU. One of the questions asked by the Eurobarometer of people throughout the EU was "What does the EU mean to you?" Figure 2 shows the answers of that question in the UK. Among the top 5 answers, only the first was positive while the rest were negatives. However, answers from the rest of the EU were not less disappointing than the British ones. For example, in 2010, the Austrians outnumbered all the EU seeing the EU as wasting money with $52 \%$, and $50 \%$ seeing it as causing more crime.

1 The figure contains only the 15 Member States which existed in 1996 to be able to compare the situation between the two times. 
All these reasons led the British to dislike the EU, and they did not make any effort to know more about it or how it works. Figure 3 shows the percentage of the British who understand how the EU works, compared with the average for EU citizens in general from 2005 to 2016. Note that less than half the British know and understand the way the EU functions, while more than the half do not understand how it works. In fact, more than the half of all EU citizens do not understand how it works.

Figure 2. What does the EU mean to British? (Top 5 answers)

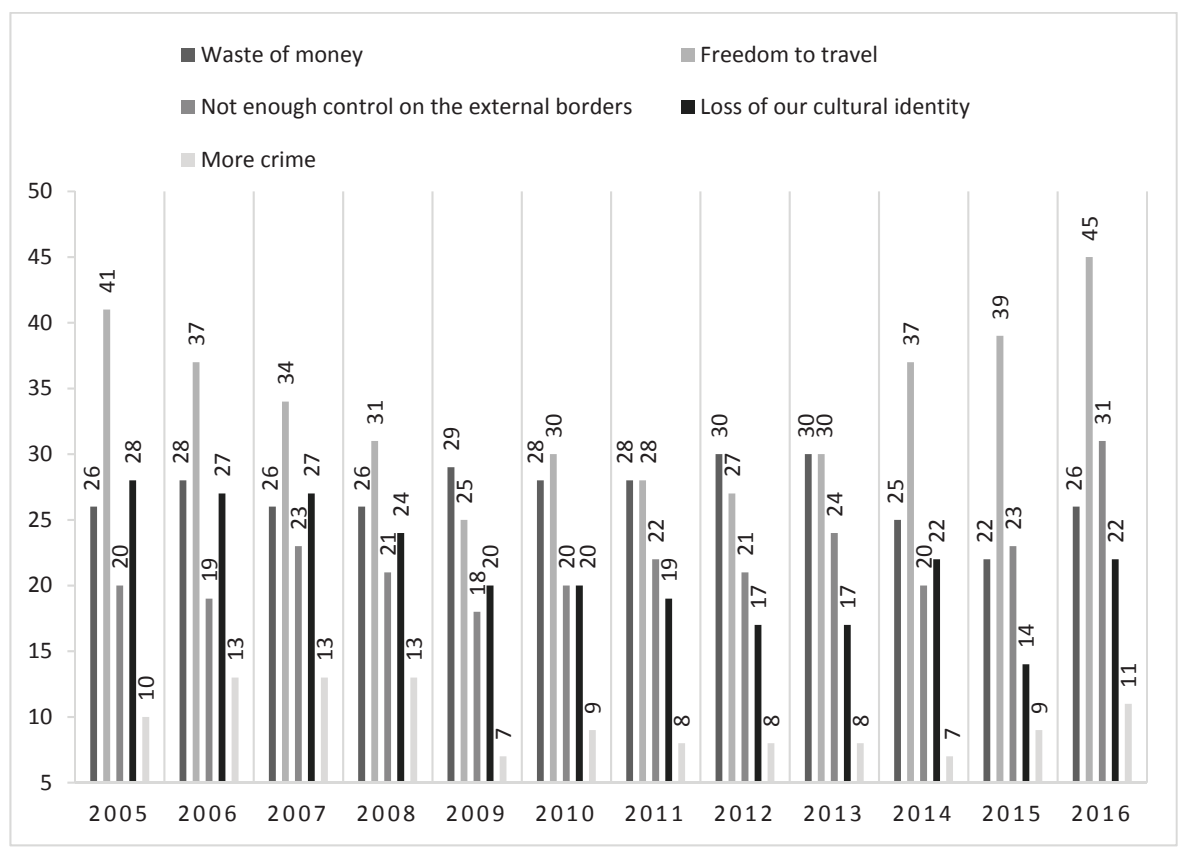

S o u r c e : based on data from: (www1).

As evident in figure 2, one of the main fears of the British regarding the EU was the loss of cultural identity, which was considered a reflection of the national identity. That harmonizes with (Curtice, 2016), who found that many British showed concerns towards the cultural consequences, but were likely to believe that there are economical benefits from EU membership. He also believes that fear of a cultural threat is reflected through the rising of Euroscepticism in the UK. Moreover, $47 \%$ of the British agreed that the EU is un- 
dermining the British cultural identity while 30\% disagreed (Natcen Social Research, 2016).

Figure 3. Do you understand how the EU works? (Yes answers)

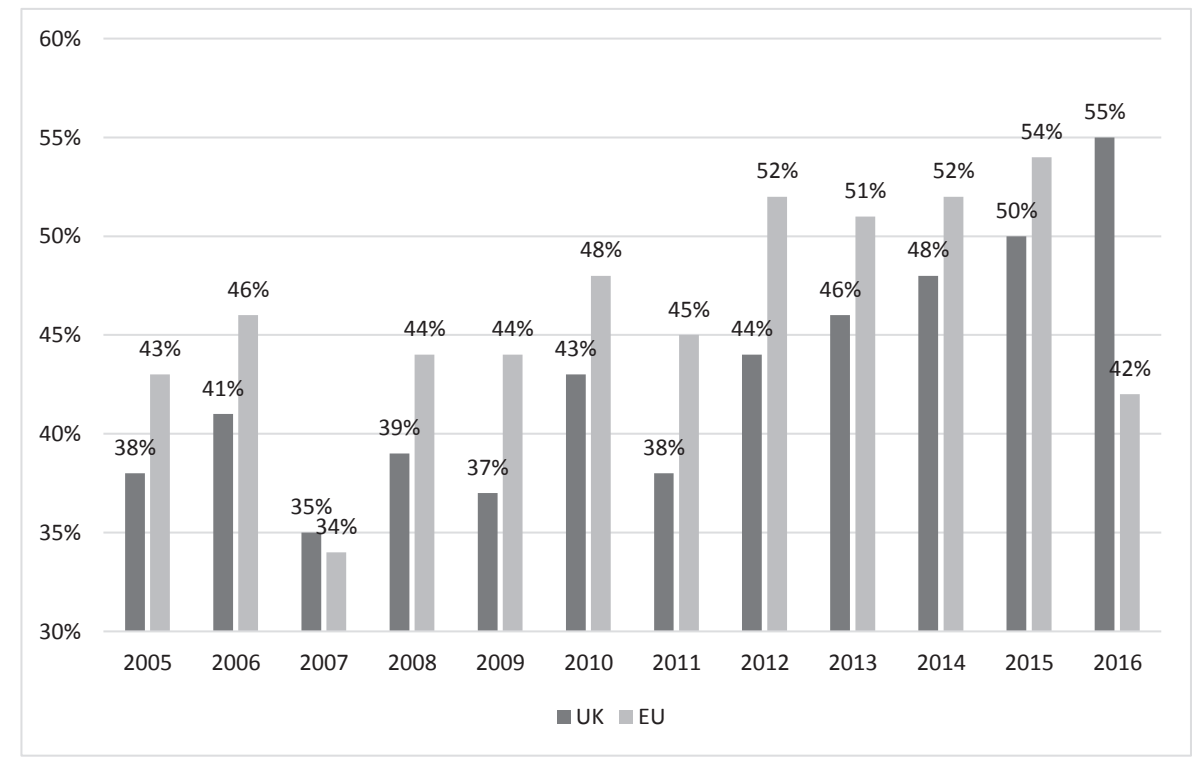

S o u r c e : based on data from: (www1).

Generally speaking, nationality - considered as a question of loyalty and affiliation, and as a matter of identity, alongside gender, age, religion, etc. - can be regarded as a criterion for a sense of national identity. Again, the original question posed by the Eurobarometer was "Do you see yourself as Nationality only, Nationality and European, European and Nationality, European only?" Figure 4 shows the percentage of British people who see themselves only British. Usually around $60 \%$ or more feel only British; this dropped below $50 \%$ in 2005 and 2007, but only because the Eurobarometer added another choice - "Don't Know" - which affected the statistics for all member states in these two years. 
Figure 4. British who feel only British from 1996 to 2016

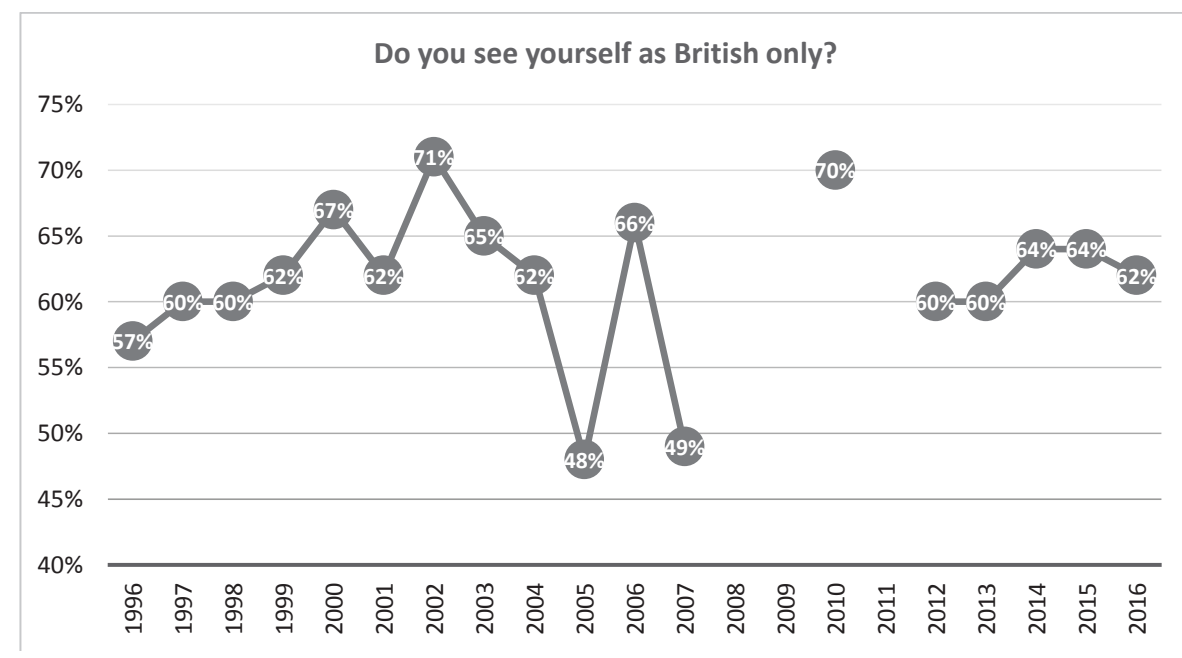

S o u r c e : from 1996 to $2016^{2}$ based on: (www1).

Why the question of identity is so vital for the British? Britain faced a kind of cultural isolation because of its geographical nature, and its culture and traditions had been conserved especially well due to the country is not having faced any foreign invasion since 1066. Moreover, the British are very proud of their historical heritage. The Tudor era, the most taught period in British schools, is considered the beginning of modern England, with figures such as Henry VIII, Elizabeth I, and Shakespeare, the separation from Rome and the beginning of the Church of England, and the defeat of the Spanish Armada, beginning the sovereignty of the British naval fleet on the seas and oceans. The most well-known icons of British national identity are the monarchy and the royal family. However, Storry and Childs (1997) argue that the monarchs were usually non-English, citing examples of the Houses of Tudor and Stuart (Welsh and Scots, and thus British but non-English) and the Houses of Orange and Hanover (both continental). Last and not least, evidence for conserving and cherishing cultural traditions compared with its neighbours, British ethnicity did not have a great change during the last nine centuries, despite the existence of many foreign communities in London and Liverpool as well as the influences from the overseas colonies (Storry \& Childs, 1997), and all that these communities were able to do.

2 Data for 2008, 2009 and 2011 are not available. 


\section{The Populism and the Anti-European feeling}

Another reason that cannot be ignored, for the British not feeling European, is the rise of populist movements and cultural backlash against globalisation as a reaction to progressive cultural changes, especially among the elder and less educated portion of the population, who - far more than young and well-educated people - supported Brexit because they were less likely to benefit from the EU economically and culturally.

Since the 1960s, voting for the populist parties in both national and European parliamentary elections rose from $5.1 \%$ to $13.2 \%$, while the share of seats rose from $3.8 \%$ to $13.2 \%$ (Inglehart \& Norris, 2016)

As the main populist party in the UK, UKIP (the UK Independence Party) took a nativist approach against immigrants, playing on xenophobic fears, in particular after the terrorist attacks in Brussels and Paris, and the increased flow of refugees in 2015. Immigration has ranked as a top concern for UK citizens over the last ten years (figure 10 shows the evolution of the situation for UK and EU citizens during 2006-2016). UKIP also promoted and appealed to nostalgia for the golden days of the English empire, before the EU, by using slogans such as "we want our country back" and "believe in Britain."

Inglehart and Norris (2016) argue that the UKIP leave campaign focused on the days when the majority of the society were white Anglo-Saxons, factories were providing well-paying jobs for the workers, and the parliament was sovereign. UKIP won only one seat in 2015's UK parliamentary elections, their first since the party was officially founded in 1993. However, from the outset, the party focused on the EU parliamentary elections, although Nigel Farage, the party's leader, once said "I want to free this country from the European Union" (BBC, 2013). Starting with the 1999 European Parliament election, UKIP started to win seats, the number gradually rising with each election till 2014, when it won 24 - more seats than either Labour or the Conservatives, the two pillars of British political life ${ }^{3}$ (figure 5 shows the evolution of the seats won by the Conservatives, Labour, UKIP, and Liberal Democrats since the first EP elections in 1979 until 2014).

${ }^{3}$ Janice Atkinson was expelled from the party in March 2015, Steven Wolfe and Diane James resigned from the party in October and November 2016 respectively, and Roger Helmer resigned from the European Parliament in June 2017. Thus, the party is now represented by 20 members. 
Yet why would a Eurosceptic party try so strongly to win seats in the European Parliament? Alan Sked, the UKIP founder who resigned the leadership in 1997, opposed the idea of entering the European Parliament elections, wanting the party to concentrate on the UK Parliament instead of having seats in the European Parliament, describing it as a "gravy train". As stated, UKIP was unable to gain any seats in the British parliamentary elections until 2015, although this was supposed to be their main goal, while the Pro-European party, the Liberal Democrats won only one EP seat in 2014, having won 12 and 11 seats in 2004 and 2009 respectively. This includes not only UKIP, but also other Eurosceptic parties all over Europe, like the Front National (National Front) in France, Freiheitliche Partei Österreichs (Freedom Party of Austria), Vlaams Belang (Flemish Interest) in Belgium, and so on.

Figure 5. Main British Parties in the European Parliament (1979-2014)

(Number of seats)

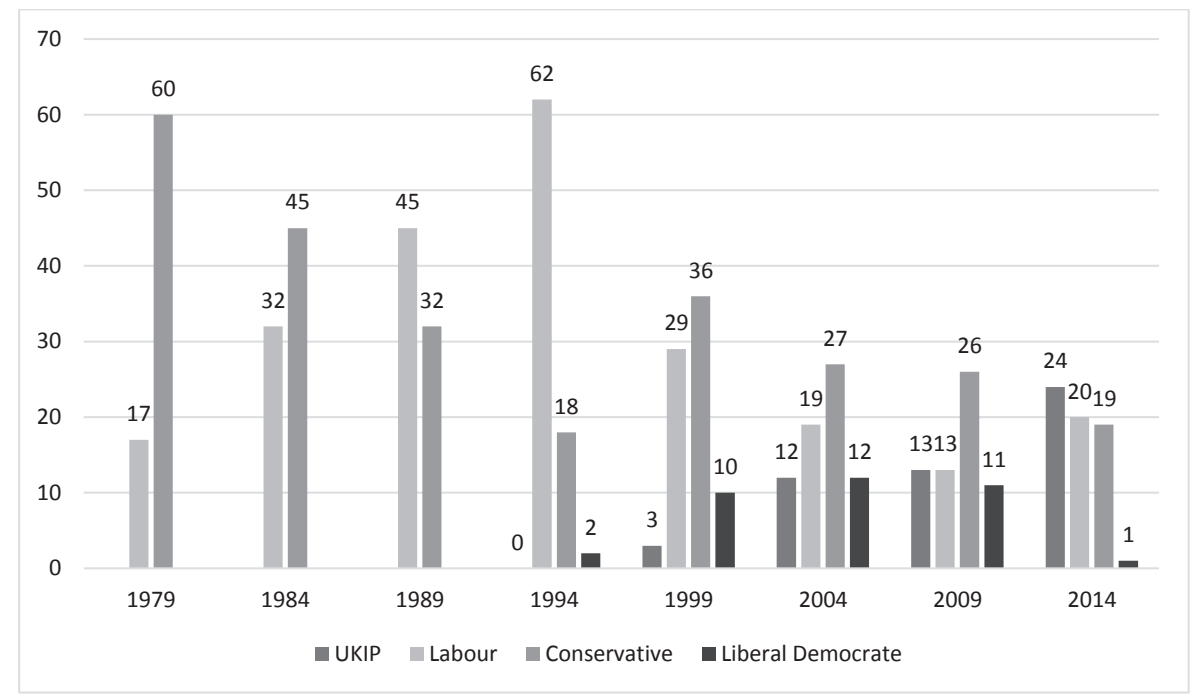

Source: based on the European Parliament Elections results from 1979 to 2014 from: (www2).

The increasing support for these populist parties was a logical result of the oppositional view of "Europeanness" (Fligstein, Polyakova \& Sandholtz, 2012). Figure 6 shows the evolution of the vote's percentage in the EP for the main populist parties during the elections from 1979 to 2014. However, UKIP proved 
that it did not have to get a lot of seats in the British Parliament in order to influence views in the street; even with only one seat the party was able to raise anti-European feeling among the British public, pushing the Conservatives to go forward for the Brexit referendum.

Figure 6. Votes percentage for the main populist parties in the EU for European Parliament Elections from (1984-2014)

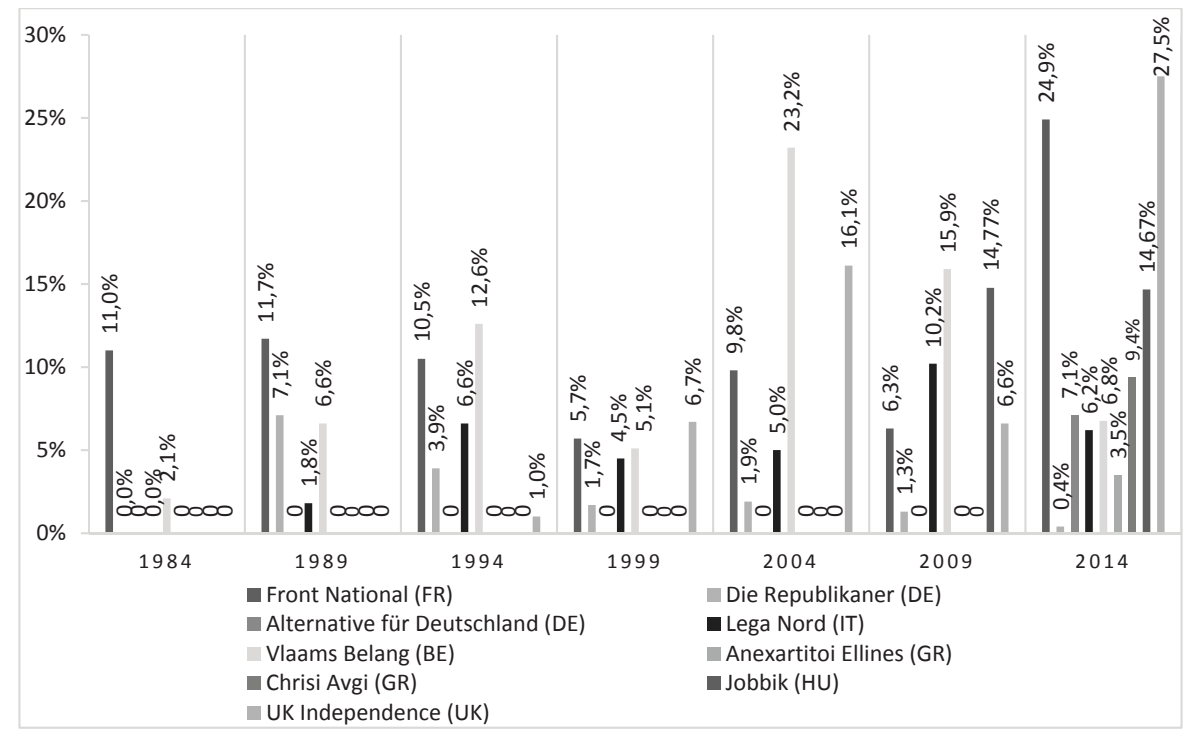

S o u r c e : based on the European Parliament Elections Results (1984-2014) from: (www2).

\section{Sovereignty}

Another important element that shaped the British feeling towards the EU is sovereignty.

In her Brexit speech to the Conservative party, shortly after triggering Article 50, which allows any member state to withdraw from the EU, Theresa May pointed that leaving the EU with its supranational institutes would bring back sovereignty to the UK to be a full independent country. In 1972, the British Parliament legislated the "European Communities Act 1972 Chapter 68" the accession to the 
European Communities ${ }^{4}$. The act gave primacy to the EU law over British law, which was considered by many to mean the diminishing of British Parliament sovereignty. Vaughne Miller (2010) suggested that $6.8 \%$ primary legislations and $14.1 \%$ secondary legislations were driven by the EU obligations during the period 1997-2009. According to House of Commons (2010), 186 acts of primary legislations out of 1302 (14.28\%) acts issued during 1980-2009 had EU origins. Figure 7 shows the distribution of the 186 acts according to their EU influence.

Moreover, for the secondary legislations during (1997-2009), 1834 over 19897 legislations (9.22\%) had been influenced by the European Communities Act 1972, while 997 legislations (5.01\%) had been influenced by other EU laws, thus, the total secondary legislation during (1997-2009) are 2831 (14.2\%) from the secondary legislations. Figure 8 shows the evolution of the situation from (1997-2009). During the Prime Minister speech on 17 January 2017, about the 12 points plan for Brexit, she declared that Brexit means "control of our own laws". However, according to the "White Paper Brexit" of February 2017, the sovereignty of the British Parliament has remained intact during membership with EU, although the public have not always felt that (HM Government, 2017).

Figure 7. British primary legislations which had EU origins, number of Acts and percentage of the total acts (186)
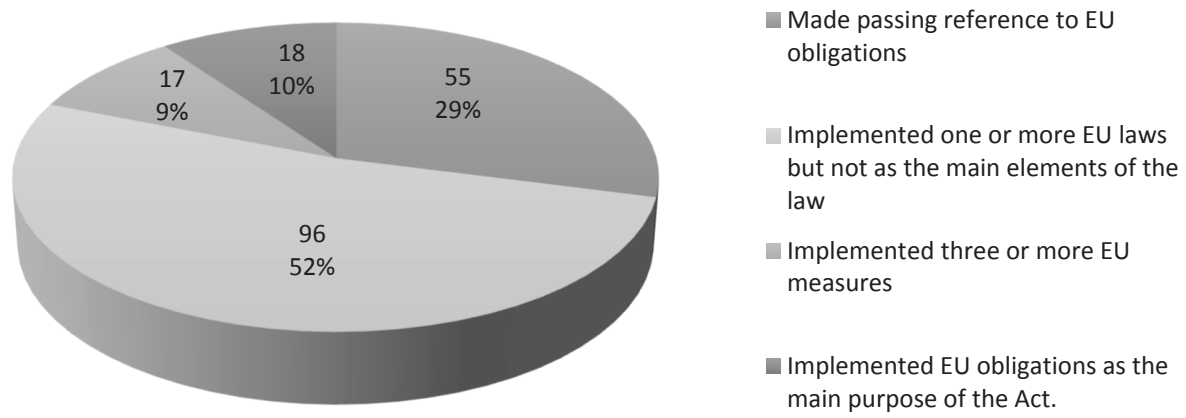

S o u r c e : based on data from: (House of Commons, 2010).

4 The communities mean The European Economic Community (EEC), The European Coal and Steel Community (ECSC), and the European Atomic Energy Community (EAEC). 
Figure 8. British secondary legislations which had EU origins

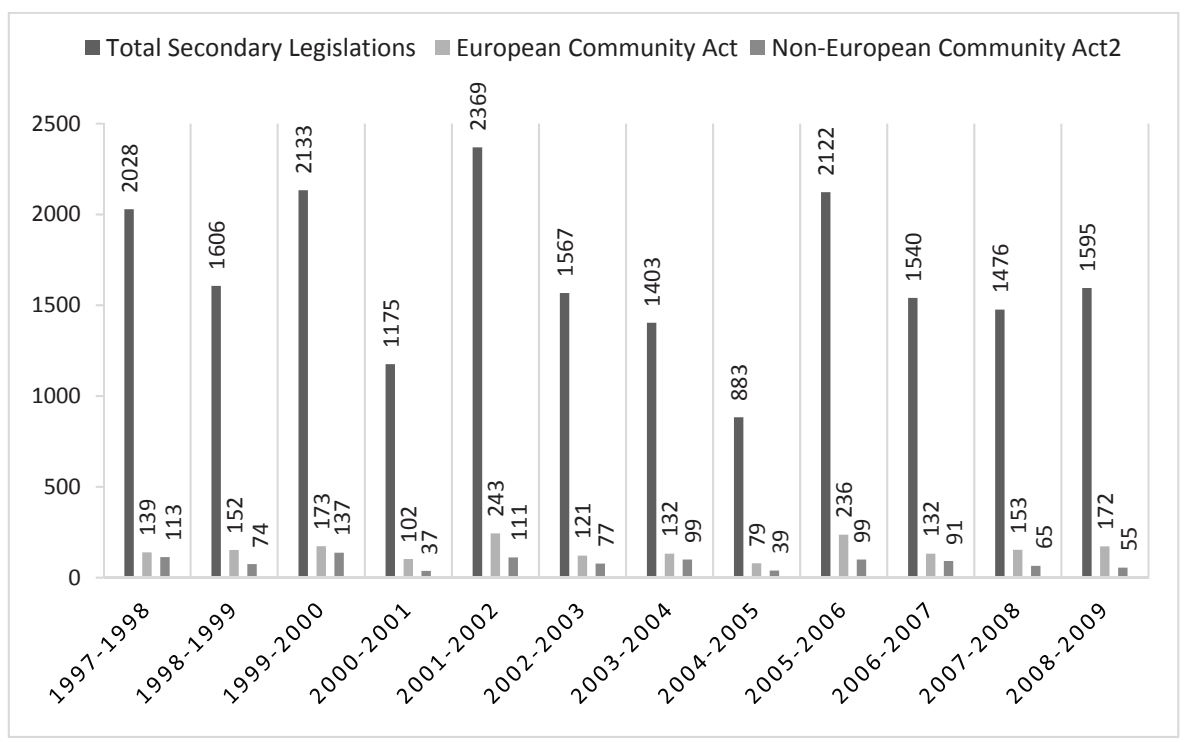

S o u r c e : based on data from: (House of Commons, 2010).

\section{BREXIT COST}

The results of the Brexit referendum led to a messy situation in the financial markets, the fall of the pound to its lowest level against the dollar in more than 30 years, and the loss of the AAA credit rating for the UK for the first time since 1978, dropping to AA with negative outlook by Moody's, Standard and Poor's, and Fitch.

One of the daily debates in the UK after the referendum was over the cost of Brexit with the use of positive or negative economic data by the leave and remain proponents to support their points of view. According to the CER (Centre for European Reform), the British economy is " $2.5 \%$ smaller than it would be if the UK had voted to remain in the European Union" (Springford, 2019). The same research found that the leave vote costs $£ 500 \mathrm{~m}$ per week, which is $£ 150$ $\mathrm{m}$ more than what the leave campaign claimed that being a part of the EU cost the public purse each week. Figure 1 compares UK data with that of a "doppelgänger UK" created using data from 22 countries with economic profile close to that of the UK. 
Figure 9. The cost of Brexit to 2018 Q3

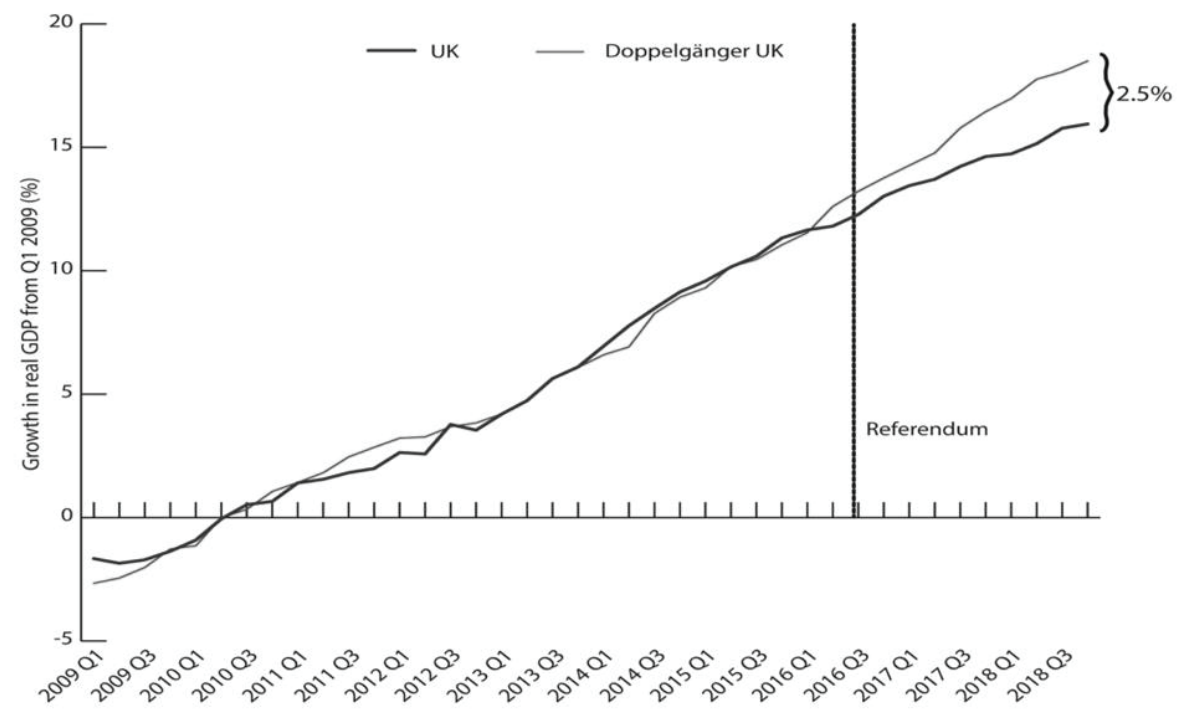

S o u r c e : CER (Springford, 2019).

Future costs are also becoming evident. With Brexit, London will lose its current position as the capital and main provider of banking services to the EU. Winters (2018) finds that Brexit will lead of British banks and financial firms to lose the "financial passport" allowing them to provide financial services to any other member state. Sapir, Schoenmaker and Véron (2017) find that 17\% of all UK banking assets (35\% of London wholesale banking) will relocate within the EU after Brexit. This movement will cost the UK about $€ 1.8$ trillion. Schelkle (2018) finds that "some US banks may relocate to places like Warsaw instead, because they do not trust that the Euro Area will survive".

Another important cost of the Brexit is the cost of trade with the rest of the world, as the UK will need to negotiate trade agreements with other countries; as part of the Single Market, the UK does not need any trade agreements. De Mars, Murray, O'Donoghue and Warwick (2018) find that after Brexit the UK and the EU might have trade agreements with the same third country with different tariffs on the same products. 


\section{ConCLUSION}

The Brexit referendum has stimulated debate across Europe about the purpose of the EU and the appropriate place of the UK in Europe. The relationship between the UK and Europe has always been thorny. Margaret Thatcher famously stated that "during my lifetime most of the problems the world has faced have come, in one fashion or other, from mainland Europe, and the solutions from outside it" (The Economist, 2002). This quote emphasises the British feeling of superiority as a saviour to Europe from the troubles and problems it gets involved in. The same method has always been used to impose opinion, based on British interests as a first priority to anything, even where negotiations concern the public interest of Europe as a whole forgetting that in politics there is no free lunch. Drake (2018) emphasizes that the British membership to the EU has become harder and harder. Such an attitude will make the decision of divorce appear better for both parties, the EU and the UK. Divorce is better than a bad marriage. Geddes (2004) states that British relations with the EU were "conditional and differential," which negatively affected both local British politics and the role played by the UK in the development of the EU, political and historical tensions had a further negative effect. Geddes points out that, thanks to these issues of engagement, the UK was unable to prioritize some British preferences into the EU, most specifically free trade and participation in NATO. However, the low rate of feeling European did not only affect the late decision to join the EEC, but also caused unstable relations between the EEC and the UK. Jenkins (1983) criticizes Britain's problem as "a schizophrenia, inability to decide its place in the world". Appeals to "the empire" and "the golden age" or calls to "protect our heritage, protect our borders" - these more have been used by the populist parties in the UK, while similar messages have been used by the populist leaders elsewhere in Europe and in the USA.

The result of the vote has sparked a spark between the Eurosceptics all over the EU, that made them achieve significant scores (e.g.: in France during the first round of the presidential elections, two Eurosceptic candidates - Mélenchon and Le Pen - won $40 \%$ of the votes). Bickerton (2018) finds that Brexit raised the issue of the ability of a state to represent the people will.

The nostalgic feeling is most likely to affect in the older citizens who remember and compare the past and the present, and who respond to appeals to "traditional values." Thus the mainstream support for the populist calls to leave the EU came from the elder generation rather than the younger. The cam- 
paign to leave Europe has provoked - among several things - a crisis between the British sovereignty and the EU supranational governance. The campaign relied on what now appear to be misinformation and false nostalgia. Staiger and Martill (2018) conclude that "Brexit is a classic wicked problem". In the period following the referendum, new parliamentary elections were held. Two votes of no confidence in May were triggered (one by her own party and one by MPs). The parliament is floundering, unable to decide whether to approve the May's agreement with Brussels, leave without a deal, or making changes in the deal between London and Brussels.

One fact is very clear now, the UK is undoubtedly in trouble. The Brexit referendum has opened Pandora's Box.

Figure 10. Immigration as a main concern for British and EU citizens

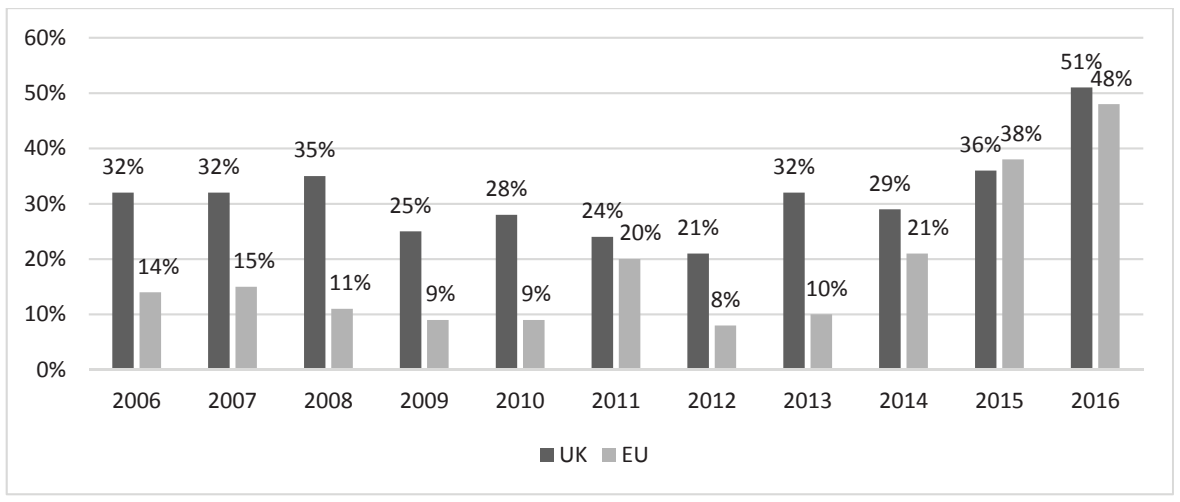

S o u r c e : based on reports (2006-2016): (www1).

\section{ACKNOWLEDGEMENT}

I would like to thank the Editor (Mrs. Agnieszka Żołądkiewicz-Kuzioła) and the two anonymous reviewers for the comments provided in relation to the earlier version of the paper. Finally, I would like to express my deepest gratitude to Prof. Garrett Epp for the proofreading and to Prof. Ewa Miklaszewska for her comments on the first version of the paper. Any remaining errors are solely the author's responsibility. 


\section{REFERENCES}

BBC (2011). Sarkozy: There are now clearly two Europes, http://www.bbc.com/news/ world-europe-16138375 (accessed: 05.07.2017).

BBC (2013). I am odd (for a politician): UKIP leader Nigel Farage says, http://www.bbc. com/news/uk-politics-20931123 (accessed: 05.07.2017).

Becker, J., \& Knipping, F. (1986). Power in Europe? Great Britain, France, Italy and Germany in a postwar world. Berlin - New York: Walter de Grapter.

Bickerton, C. (2018). The Brexit iceberg. In B. Martill, U. Staiger (Eds.). Brexit and Beyond: Rethinking the Futures of Europe. London: UCL Press.

Curtice, J. (2016). A Question of Culture or Economics? Public Attitudes to the European Union in Britain. The Political Quarterly, 87(2), 209-18. https://dx.doi. org/10.1111/1467-923X.12250.

Daddow, O.J. (2004). Britain and Europe since 1945: Historiographical Perspectives on Integration. Manchester: Manchester University Press.

De Gaulle, C. (1967). Paroles publiques - Conférence de presse du 16 mai 1967 - Ina. fr, http://fresques.ina.fr/de-gaulle/fiche-media/Gaulle00129/conference-de-pressedu-16-mai-1967.html (accessed: 06.05.2019).

De Mars, S., Murray, C., O’Donoghue, A., \& Warwick, B. (2018). Bordering two unions: northern ireland and brexit (1st ed.). Bristol: Bristol University Press.

Drake, H. (2018). France, Britain and Brexit. In B. Martill, U. Staiger (Eds.). Brexit and Beyond: Rethinking the Futures of Europe. London: UCL Press.

Ellison, J. (2000). Threatening Europe, Britain and the Creation of the European Community, 1955-58. New York: Palgrave.

Fligstein, N., Polyakova, A., \& Sandholtz, W. (2012). European Integration, Nationalism and European Identity: European Integration, Nationalism and European Identity. Journal of Common Market Studies, 50(s1), 106-122. https://dx.doi.org/10.1111/j.14685965.2011.02230.x.

Geddes, A. (2004). The European Union and British Politics. New York: Palgrave Macmillan.

HM Government (2017). The White Paper: United Kingdom's exit from and new partnership with the European Union.

House of Commons (2010). How much legislation comes from Europe. Research Paper, $10 / 62$.

Inglehart, R.F., \& Norris, P. (2016). Trump, Brexit, and the Rise of Populism. HKS Working Paper, RWP16-026.

Jenkins, R. (1983). Britain and the EEC: Present and Future. In Jenkins, R. Britain and the EEC: proceedings of Section F (Economics) of the British Association for the Advancement of Science, Liverpool, 1982. London: Macmillan.

Jones, R.A. (2001). The Politics and Economics of the European Union, Second Edition. Cheltenham: Edward Elgar Publishing LTD.

Martin, G.J. (2013). General de Gaulle's Cold War. New York: Berghahen Books.

May, A. (1999). Britain and Europe since 1945. London: Longman LTD. 
May, A. (2001). Britain, the Commonwealth and Britain's Applications to Join the European Communities. New York: Palgrave Publishers LTD.

Milward, A.S. (2002). The rise and fall of a national strategy (1945-1963). London: Frank Cass Publishers.

Natcen Social Research (2016). Do we feel European and does it matter? What UK Thinks: EU.

Porter, B. (1983). Britain, Europe and the world 1850-1982: delusions of grandeur. Boston: G. Allen \& Unwin LTD.

Saint-John Perse Foundation (1929). Aristide Briand speech to the Assembly of the League of Nations, http://fondationsaintjohnperse.fr/en/la-programmation-culturelle/archives/europe_documentation/discours-briand-1929 (accessed: 01.07.2017).

Sapir, A., Schoenmaker, D., \& Véron, N. (2017). Making the best of Brexit for the EU27 financial system.

Schelkle, W. (2018). What impact will Brexit have on the euro area? In B. Martill, U. Staiger (Eds.). Brexit and Beyond: Rethinking the Futures of Europe. London: UCL Press.

Shawcross, W. (2002). Queen and country: the fifty-year reign of Elizabeth II. New York: Simon \& Schuster.

Springford , J. (2019). Centre for European Reform - The cost of Brexit to December 2018: Towards relative decline? https://www.cer.eu/insights/cost-brexit-december2018-towards-relative-decline (accessed: 15.04.2019).

Staiger, U., \& Martill, B. (2018). Rethinking the Futures of Europe. In B. Martill, U. Staiger (Eds.). Brexit and Beyond: Rethinking the Futures of Europe. London: UCL Press.

Steinnes, K. (1998). The European Challenge: Britain's EEC Application in 1961. Contemporary European History, 7(1), 61-79. https://dx.doi.org/10.1017/S0960777300004768

Storry, M., \& Childs, P. (1997). British cultural identities. Oxford: Routledge.

The Churchill Society (1946). Winston Churchill speaking in Zurich, http://www.churchill-society-london.org.uk/astonish.html (accessed: 01.07.2017).

The Economist (2002). Margaret Thatcher Like love to hatred turned, http://www.economist.com/node/1056815 (accessed: 01.07.2017).

The Guardian Newspaper (2012). Back when Britain was banging on Europe's door, http://www.theguardian.com/commentisfree/2012/oct/13/britain-europe-davidcameron-eu (accessed: 01.07.2017).

The Labour Party Manifesto (1974). http://www.labour-party.org.uk/manifestos/1974/ Feb/1974-feb-labour-manifesto.shtml (accessed: 01.07.2017).

Urwin, D.W. (1991). The community of Europe. London: Pearson Education Limited.

Wall, S. (2008). A Stranger in Europe: Britain and the EU from Thatcher to Blair. Oxford: Oxford University Press.

Winters, L.A. (2018). What difference does brexit make? In J. Drake-Brockman, P. Messerlin (Eds.). Potential Benefits of an Australia-EU Free Trade Agreement, Key Issues and Options. Adelaide: University of Adelaide Press.

(www1) Eurobarometer Reports, http://ec.europa.eu/commfrontoffice/publicopinion/ archives/eb_arch_en.htm (accessed: 01.08.2017).

(www2) Parliaments and governments database, http://www.parlgov.org (accessed: 25.08.2017). 